\author{
G.R. Useinova1 ${ }^{1}$, A. Zhamalbekova ${ }^{2}$, A. Jainak ${ }^{1}$ \\ ${ }^{1}$ Al-Farabi Kazakh national University, Kazakhstan, Almaty, \\ e-mail: gulnara_usein@mail.ru, e-mail: oss.kenfly@gmail.com \\ ${ }^{2}$ Kazakh Humanitarian law innovative University, Kazakhstan, Semipalatinsk

\section{FEATURES OF THE EMERGENCE AND DEVELOPMENT OF NOTARIES IN THE REPUBLIC KAZAKHSTAN AND FOREIGN COUNTRIES: COMPARATIVE LEGAL ANALYSIS}

The article is devoted to one of the oldest legal institutions - the Institute of notaries. Throughout the history of the state and law development, notaries have been an integral part of the legal system of most countries, since the functions performed by notaries are objectively demanded by society.

Almost all research authors agree that the entire history of the notary goes back to Ancient Rome. Some authors-researchers note that analyzing the history of the emergence of the notary, you should pay attention to the legal monuments of Ancient Babylon, namely the Laws of Hammurabi.

Of particular interest, according to researchers, is the fact that even at that time, transactions in writing were made on clay tablets according to strictly defined rules. There are two main notary systems in the modern world. This is Latin and Anglo-American.

The authors note that certain stages of the development of the Institute of notaries in Kazakhstan coincide with the development of notaries in Russia. Since 1991, the path of development of the Kazakh notary in an independent, sovereign state has begun. And also consider the historical facts that provide the use of writing to make a deal.

Key words: society, state, law, obligation, guarantor, power of attorney.

$$
\begin{gathered}
\text { Г.Р. Усеинова', А. Жамалбекова², А. Жайнақ }{ }^{1} \\
\text { 'Әл-Фараби атындағы Қазақ, ұлттық, университеті, } \\
\text { Қазақстан, Алматы қ., е-таil: gulnara_usein@mail.ru } \\
{ }^{2} \text { Қазақ, инновациялық, гуманитарлық, заң университеті, } \\
\text { Қазақстан, Семей қ., е-mail: oss.kenfly@gmail.com } \\
\text { Қазақстан Республикасында және } \\
\text { шет елдерде нотариаттың пайда болуы мен } \\
\text { дамуының ерекшеліктері: салыстырмалы құқықтық талдау }
\end{gathered}
$$

Мақала ежелгі заң институттарының бірі - нотариаттық мекемеге арналған. Нотариаттар мемлекет пен құқықтың даму тарихында көптеген елдердің құқықтық жүйесінің ажырамас бөлігі болып табылады, өйткені нотариустар атқаратын функцияларды қоғам объективті түрде талап етеАі.

Зерттеушімердің барлығы дерлік нотариаттардың бүкіл тарихы ежелгі Римнен басталады деген пікірде. Кейбір зерттеу авторлары нотариаттың тарихын талдағанда ежелгі Вавилонның заңды ескерткіштеріне, атап айтқанда Вавилон мемлекетінің патшасы шығарып, өз халқына өсиет ретінде қалдырылған Хаммурапи заңдарына назар аударған жөн. Зерттеушілердің пікірі бойынша, сол уақытта жазбаша түрдегі мәмілелер қатаң белгіленген, мемлекеттің барлық тұрғындарына тиесілі, орындауды талап ететін ережелерге сәйкес сазды тақшаларда жасалды. Тарихта орын алған мұрағаттағы дәлелдемелер зерттеу жұмысының негізін қалаған.

Қазіргі әлемде нотариаттардың екі негізгі жүйесі бар. Бұл ^атын және англо-америкалық жүйелер ретінде айғақталған.

Авторлар Қазақстандағы нотариаттар институтының дамуындағы белгілі кезеңдер Ресейдегі нотариаттардың дамуымен сәйкес келетіндігін айтады. 1991 жылдан бастап қазақстандық нотариаттардың тәуелсіз, егемен мемлекетте даму жолы басталды. Сонымен қатар келісім шарттарды аяқтау үшін жазбаның жазбаша негізде қолданылуын растайтын тарихи фактілер қарастырылады.

Түйін сөздер: қоғам, мемлекет, заң, міндеттеме, кепілдік, сенімхат. 


\author{
Г.Р. Усеинова ${ }^{1}$, А. Жамалбекова ${ }^{2}$, А. Жайнак ${ }^{1}$ \\ 'Казахский национальный университет им. аль-Фараби, \\ Казахстан, г. Алматы, e-mail: gulnara usein@mail.ru, e-mail: oss.kenfly@gmail.com \\ ${ }^{2}$ Казахский гуманитарно-правовой инновационный университет, Казахстан, г. Семей \\ Особенности возникновения и развития нотариата \\ в Республике Казахстан и зарубежных странах: \\ сравнительно-правовой анализ
}

\begin{abstract}
Статья посвящена одному из древнейших правовых институтов - институту нотариата. На протяжении всей истории развития государства и права нотариат является составной частью правовой системы большинства стран, поскольку осуществляемые нотариусами функции объективно востребованы обществом.

Практически все авторы-исследователи сходятся во мнении, что вся история нотариата восходит к Аревнему Риму. ОтАельные авторы-исследователи отмечают, что, анализируя историю возникновения нотариата, следует обратить внимание на правовые памятники Аревнего Вавилона, а именно Законы Хаммурапи. Особый интерес, по мнению исследователей, вызывает тот факт, что уже в то время слелки в письменной форме совершались на глиняных табличках по строго определенным правилам

В современном мире существуют две основные системы нотариата. Это - латинская и англоамериканская.

Авторы отмечают, что отдельные этапы развития института нотариата в Казахстане совпадают с развитием нотариата в России. С 1991 года начался путь развития казахстанского нотариата в независимом, суверенном государстве. А также рассмотрены исторические факты, удостоверяющие использование письменности Аля оформления сАелок.
\end{abstract}

Ключевые слова: общество, государство, закон, обязательство, поручительство, Аоверенность.

\section{Introduction}

It is no secret that one of the oldest legal institutions is the Institute of notaries. In Latin, the term "notorious" means scribe, Secretary.

With the development of commodity and money turnover, new types of relations arise that require their legal regulation. With the conclusion of an increasing number of transactions in writing, there is a need for "special persons whose duty was to record the transactions in writing and keep copies of them" (Patrashchuk, 2003: 38). Thus, the mandatory conditions for the formation of the Institute of notaries were commodity-monetary relations and writing.

Almost all research authors agree that "the entire history of the notary goes back to Ancient Rome" (Skripilev, 1998: 3). Notarial activity in Ancient Rome involved: scribes in the public service (scribe); scribes in the service of private individuals (exceptores or notarii); a special institution - the Institute of tabellions (tabelliones).

Thus, the office of scribes in the civil service (scribae) was held only by Roman citizens and was considered life-long. They were registered with the magistrates and received a certain salary from the state Treasury. Their duties included: making public documents, maintaining public accounts, issuing statements and copies to those who wished, and certifying documents.
As scribes in the service of private individuals were free men who were freely employed as household secretaries to the rich, or slaves. The first of them were called-exceptores, the second-notarii.

\section{Main part}

If we talk about the institution of tabelions, it is "the category of persons who, without being in the public service, were engaged in the form of free trade in drawing up legal acts and court papers, under the control of the state, for anyone in need of them, for remuneration established by law" (Lyapidevsky, 1875: 20-21). This institution, as modern science notes, is the prototype of the organization called "notary". Due to the lack of historical data, it is impossible to determine the exact time of the establishment (Devyatkina, 2020: 4).

After the fall of the Western Roman Empire, all documents made by notaries were referred to as" instrumenta publica "or"chartae publicae". The word "tabellion" disappears and the word "notary" appears (Femilidi, 1902).

Some authors-researchers note that analyzing the history of the emergence of the notary, you should pay attention to the legal monuments of Ancient Babylon, namely the Laws of Hammurabi. Of particular interest, according to researchers, is the fact that even at that time transactions in writing 
were made on clay tablets according to strictly defined rules (Рифтин, 1937: 16). An oath was used as an interim measure. The tablet was filled in by a scribe who had the necessary knowledge of the correct design. Tablets were kept by the owners in vessels, pitchers, and places with the same as private documents - in the temple archives (Zatsepina, 2000: 21). Similar functions in Ancient Egypt were performed by agoranomos, in Ancient Greece-by hieromemneses or epistates, who had the rank of priests, and were obliged to accept and preserve contracts as evidence in case of disputes (Danilova, 2014).

Thus, it should be noted that the societies of ancient States they needed specialists in drafting documents that ensure the indisputability of acquired rights, as well as the need to store legal documents.

As you know, there are two main notary systems in the modern world. This is Latin and AngloAmerican. They are fundamentally different from each other.

The modern model of the Latin notary is based on the French law on the principles of the organization of notaries from March 16, 1803 (Schwachtgen, 2002).

This Law marked the beginning of the development of notaries in Europe, in particular, and in the world as a whole. It is also worth noting that the relevant action has not lost its legal force to this day, also, it was a legal model for other legislative acts regulating notarial activity not only in Europe but also in many other countries (Mizincev, 2012: 20).

The law of 1803 eliminated various categories of persons authorized to draw up official documents. They were introduced instead of the position fonctionnaires publics.

In particular, the Law contained the following provision: "Along with officials who resolve disputes, public peace requires the presence of other officials who... make the parties aware of the meaning of contractual obligations... give them the character of an authentic act and the force of a judicial decision... prevent conflicts from arising... These disinterested advisors... kind of voluntary judges... are notaries, and this institution - the notary" (Get'man-Pavlova, 2011)

The main principles of the Latin notary, which fix the legal status of a notary, include the following:

- The notary is a public official. The state transfers to it the powers that it exercises on its behalf and under its control;

- Notary - a person of a free legal profession; independently organizes their work; bears property responsibility for the losses caused;
- The main function of a notary is to give private agreements an authentic character, special evidentiary and Executive force, and to protect the public interest;

- A notary receives a notary fee for the performance of notarial acts, the amount and procedure for payment of which are established by the state;

- Notaries are united in collective bodies: notary chambers that perform administrative and control functions (https://pravo163.ru/organizaciyanotariata-v-rossijskoj-federacii/).

The main models of the Latin notary are German, French, and mixed. For example, the German model of the notary is characterized by the fact that the role of the notary in conducting consultations and negotiations is insignificant. Its functions are limited only to developing a document and certifying it. The German model of notaries is close to the countries of the post-Soviet space.

The French notary model is characterized by the activity and initiative of the notary from the moment the interested person applies to him. The notary and his assistants carry out all the work on collecting the necessary documents, conducting negotiations, drawing up documents, and registering the notarial act with the competent authorities.

The most characteristic features of the French notary include:

- complete separation of the disputed jurisdiction from the undisputed one with the transfer of the latter to the exclusive jurisdiction of the notary;

- giving notarial acts the force of judicial decisions, so that their enforcement could be carried out without the participation of the judicial authority;

- granting notaries the right to recommend a successor, which led to the sale of notary posts in contrast to all other positions of a public nature;

- a lifetime appointment to the position of notaries (http://bookwu.net/book_notariat_793/).

If we talk about a mixed notary model, it operates in the Netherlands and Switzerland.

In the Anglo-Saxon legal system, there is a notary public (public notary - USA, UK), which is empowered (often only temporarily) to bear witness to simple processes. This may be the owner of a drugstore, a lawyer's Secretary (secretary downstairs), a Barber, or a salesman at a tobacco kiosk, i.e. persons who do not have legal competence.

There is no notarial certificate in the sense that it is understood in the countries of the continental legal family. The power of attorney is made in simple written form (the oral form is allowed). However, the participation of a lawyer is mandatory: lawyer (USA), notary public or solicitor (England). 
The main group of professional lawyers in the United States is lawyers who do not perform public functions but are representatives of a particular party. Notaries perform only certification functions. In England, it is allowed to mix notary and lawyer functions (solicitor).

In the United States, the organization and operation of notaries are regulated by state law. Notarial functions are performed by two categories of persons: notaries appointed by the state legislature or by the highest state officials, and fact-finding commissioners.

According to article 1 Of the law of the Republic of Kazakhstan "on notaries", "notaries in the Republic of Kazakhstan are legal institutions that provide qualified legal assistance, ensuring the protection of the rights and legitimate interests of individuals and legal entities by performing notarial acts" (https://online.zakon.kz/document).

Notarial, as a rule, occurs only in a state that reaches a certain level of civil turnover.

Throughout the history of the development of the Institute of state and law, notaries have been an integral part of the legal system of most countries, since the functions performed by notaries are objectively demanded by society (Alferov, 2006:10). Thus, in Russia, the period of formation and development of the notary can be divided into five stages.

The exact date of the emergence of notarial or quasi-notarial institutions in Ancient Russia is unknown. Some authors believe that the history of the Russian notary goes back at least to the end of the $\mathrm{XV}$ century. and that even in the judicial Records of Ivan III (1497) and Ivan IV (1550) contain references to persons who were engaged in the drafting and execution of transactions (Skripilev, 1998), and the use of written documents is mentioned in the Pskov court Charter of 1467 (Komarov, 2005: 8, 9).

Most authors attribute the beginning of the first period to the XVI century, considering the organizational basis of the notary estate "square subclerks". It was a kind of Corporation of professional scribes who specialized in making civil transactions for the benefit of those who applied to them and writing documents for a fee. Areal clerks joined together in a cooperative with mutual responsibility. Their activity was controlled by the prefects (Cheremnyh, 1999).

The second period is dated to the period from 1649 to 1866 , i.e. from the moment of entry into force of the Council decree of Tsar Alexey Mikhailovich. This stage is characterized by the haphazard formation of various notarial institutions that were created to regulate various groups of legal relations and carried out their activities under the actual control of the state.

The adoption of the Temporary provision on the notarial part of April 14, 1866, opens the third period, which is characterized by the appearance and functioning of a single universal Institute of notaries as a form of public activity of independent notaries authorized by the state to perform notarial actions, "preventing a violation of the law by lawfully excluding disputes strengthening the true will of the parties" (In a history Russion notary: 43).

This provision established that a notary is considered a civil servant, and notaries were divided into senior and junior. Notaries could certify the authenticity of signatures, powers of attorney, obligations (loan agreements, real estate rentals, etc.), and the accuracy of copies.

Having entrusted notaries with the important and responsible task of making and strengthening public acts, the legislator also defined measures to prevent possible abuse of them. In the event of violations and abuses of office, as well as for actions outside the service that are incompatible with dignity and rank, the perpetrators were subject to both disciplinary and criminal liability (Rodina 2010: 32).

The third period ended after the October revolution with the adoption of November 24, 1917. Decree No. 1 on the court, which abolished the existing state authorities, including courts, institutions of judicial investigators, Prosecutor's supervision, juries, and private lawyers (Decret, 1917). As an integral part of this system, the notary was officially abolished a little later, on March 23, 1918 , by a resolution Of the Council of People's Commissars of Moscow and the Moscow province (Elistarov, 1922: 17), since the functions that it performed were no longer relevant.

In the fourth (Soviet) period of development, the Institute of notaries was a state body that was part of the system of justice, and the state notary was considered an official (Legal act RSFSR 1974)

The following fundamental changes were made by the Resolution of the CEC of the USSR of May 14, 1926. "On the General Principles of the organization of the state notary", which established the subordination of the notary to the judicial authorities.

After the change in the social system and the change in the legal environment as a result of socioeconomic reforms in Russia, the total number of initial actions increased significantly, and the state notary could no longer cope with the increased volume of functions assigned to it. There was a 
need to create a non-state, so-called private, notary in Russia, and in 1993 the Supreme Council of the Russian Federation adopted the Basics of the legislation of the Russian Federation on notaries (Vedomosti of the Supreme Council of the RSFSR 1974: 45), radically changing its organization and activities concerning modern conditions. They marked the beginning of a new (fifth) stage, which solved the problems of the revival, formation, and development of notaries in Russia.

This document radically changed the legal basis of the notary's activity. He singled out state notaries and notaries engaged in private practice, defined the mandatory availability of legal education and training, as well as passing the qualification exam by a notary, and ultimately obtaining a license for notarial activities.

As for the development of the Institute of notaries in Kazakhstan, it should be noted that certain stages coincide with the development of notaries in Russia.

The period when Kazakhstan was part of the Russian Empire took a significant historical period. Notaries were determined by the Turkestan Governor-General from among the persons who received a certificate from the Syr-Darya regional Board in a satisfactory building of the regulations on the notarial part and took office upon taking the oath.

Before 1917, magistrates were assigned notary functions in the counties. The overthrow of the autocracy and the October uprising that followed it determined the further development of the rural and state notary. Nevertheless, civil turnover and developing a new type of socialist property relations could not do without a notary, and the Bolshevik government was forced to organize notary services in the country.

The Soviet notary developed at a time when the state did not recognize private property when civil turnover was extremely limited. At that time, the notary office was exclusively state-owned and was part of the system of justice bodies. In 1921, a Decree was issued on the introduction Of regulations on notaries and a Decree on the abolition of notary desks. in 1923, the Regulation "on the state notary" was introduced. During the Soviet period, the
Institute of notaries was also a state institution, until 1997.

In 1926, the Decree of the SNK of the USSR and the CEC of the USSR approved the Basic principles of the organization of the state notary. Since 1936, state and notary offices headed by notaries have been established in all districts and city centers.

Since 1960, due to the abolition of the Ministry of Justice, its functions for managing the notary office have been transferred to the Supreme Court. In 1973, the law of the USSR "on state notary" was adopted, on August 13, 1974-the Law of the Kazakh SSR "on state notary".

\section{Conclusion}

During this period, notarial bodies were formed in all regions of Kazakhstan. In 1983, the decree of the Presidium of the Supreme Soviet of the USSR "on the procedure for issuing and certifying enterprises, institutions, and organizations copies of documents relating to the rights of citizens" was issued. And in 1986, the Ministry of Justice of the USSR issued Instructions on filling in registers for registering notarial acts, notarial certificates, and certifying inscriptions on transactions and certified documents.

Since 1991, the path of development of the Kazakh notary in an independent, sovereign state has begun.

During the development of the rule of law in Kazakhstan, there are large-scale and significant changes in the field of jurisprudence. In 1994, the State program of legal reform in Kazakhstan was approved, including the creation of new legal institutions, the program provided for the development of the notary public, the introduction of the Institute of private notaries, the creation of a professional body that can coordinate all organizational and professional activities of an off-budget notary.

To implement this program, the law "on notaries" was adopted in 1997, which went down in the history of notaries as "revolutionary". Its role was to break the state monopoly in the field of notary services and introduce the Institute of independent notaries that meets the requirements of accelerating civil law relations in a market economy.

\section{References}

Alferov I.A. (2006) Vozniknovenie i razvitie notarial'nyh uchrezhdenij v Rossii / I.A. Alferov // Zakonodatel'stvo. [The Emergence and development of notarial institutions in Russia / I. A. Alferov // Legislation.] - - № 1. - P. 10-12.

Cheremnykh I. G. Rossijskij notariat: proshloe, nastojashhee, budushhee [Russian notary: past, present, future] /I.G Cheremnykh. M.: OKTE 1999. - 240 p. 
Dekret № 1 o sude ot 24 nojabrja 1917 g - SU RSFSR. [Decret № 1 on the court of 24 November 1917 - SU RSFSR.] - 1917. - № 4. - Article 50 .

Devyatkina O. V. Vozniknovenie instituta notariata v mire // Nauchnoe soobshhestvo studentov: Mezhdisciplinarnye issledovanija: sbornik statej po materialam II mezhdunarodnoj studencheskoj nauchno-prakticheskoj konferencii [The Emergence of the Institute of notaries in the world // The scientific community students: an Interdisciplinary study: proceedings of the II international student scientific-practical conference]. - No. 3//https:/sibac.info//sites/default/files/conf/file/stud_3_2.pdf(date accessed: 13.05.2020)

Elistratov A. I. Sobranie uzakonenij i rasporjazhenij Rabochego i Krest'janskogo Pravitel'stva 1917-1918, 1919, 1920 i 1921 // Sovetskoe pravo. 1922. № 1. [Systematic collection of instructions and orders of the Workers 'and Peasants' government.] - Moscow, 1918.

Istorija pervobytnogo obshhestva. Jepoha klassoobrazovanija [History of primitive society. The epoch of class formation.] Moscow, 1980. - 264 p.

Iz istorii rossijskogo notariata [From the history of the Russian notary] // Notary. - 1997. - P. 43-45.

Familidi A. M. Russkij notariat [Russian notary]. - SPb: Publishing Kontorovich, 1902. -35 p.

Getman-Pavlova I. Mezhdunarodnoe chastnoe pravo: Uchebnik [International private law: Tutorial] - M., $2011-640$.

Komarov, N. I. Notariat v Rossijskoj Federacii: kurs lekcij [Notary in the Russian Federation: a course of lectures] / N. I. Komarov, M.: Lex-kniga-2005-207 p.

Lyapidevsky N. P. (1875) Istorija notariata. [History of the notary.] - Vol. 1. - M. - 321 p.

Mizintsev, E. N. (2012) Organizacionno-pravovye osnovy notariata v Rossijskoj Federacii i zarubezhnyh stranah (sravnitel'nopravovoe issledovanie) : avtoref. dis. ... kand. jurid. nauk / Mizincev Evgenij Nikolaevich. [Organizational and legal bases of notariate in the Russian Federation and foreign countries (comparative legal research): author's abstract ... Cand. the faculty of law. Sciences / little fingers Evgeny Nikolaevich.] - M., 2012. - 32

Patraschuk Zh. V. (2003) Zashhita konstitucionnyh prav cheloveka i grazhdanina notariatom Rossijskoj Federacii: Diss. kand. jurid. nauk. [Protection of constitutional human and civil rights by the notary of the Russian Federation: Diss. Cand. the faculty of law. Sciences.] - Moscow. 195 p.

Riftin A. P. (1937) Starovavilonskie juridicheskie i administrativnye dokumenty v sobranijah SSSR / Pod.red. akademika Struve V.V. [Old Babylonian legal and administrative documents in the collections of the USSR / ed. by academician Struve V. V.] - M. L., $1937-175 \mathrm{p}$.

Rodina S. V., Tarakanova N. G. Notariat v sisteme pravovyh uchrezhdenij dorevoljucionnoj Rossii: provincial'nyj akcent [Notary in the system of legal institutions of pre-revolutionary Russia: provincial accent] / S. V. Rodina, N. G. Tarakanova // Notary. - 2010. - No. 4. - P. 31-35.

Skripilev E. A. Istorija rossijskogo notariata: protonotariat (institut pod'jachih), razvitie do reform Aleksandra II, notariat $\mathrm{i}$ sudebnaja reforma 1864-1874 godov // Notarial'nyj vestnik [History of the Russian Notariat: protonotariat (Institute of sub-clerks), development before the reforms of Alexander II, notariate and judicial reform of 1864-1874 // Notarial Bulletin.] - 1998. - № 9. - P. 3-9

Schwachtgen, A. (2002) Dejatel'nost' notariusa na blago grazhdanskogo obshhestva // Notarial'nyj vestnik [Notary Activity for the benefit of civil society // Notarial Vestnik.] - 2002. - V. 9. - P. 40-48

https://pravo163.ru/organizaciya-notariata-v-rossijskoj-federacii/

http://bookwu.net/book_notariat_793/

Zakon RK «O notariate» ot 14 ijulja 1997 goda [Law of the Republic of Kazakhstan “on notaries” of July 14, 1997] // https:// online.zakon.kz/document

Zatsepina S. A. (2000) Notariat v sisteme grazhdanskoj jurisdikci [Notary in the system of civil jurisdiction / Zatsepina. S.A.] -Yekaterinburg, 2000. - $187 \mathrm{p}$.

Zakon RSFSR ot 2 avgusta 1974 g. "O gosudarstvennom notariate" (utratil silu) // Vedomosti Verhovnogo Soveta RSFSR. [Law of the RSFSR of August 2, 1974 "On the state notary" (no longer valid) // Vedomosti of the Supreme Soviet of the RSFSR.] - 1974. - № 32. - St. 852.

Zakon Rossijskoj Federacii ot 11 fevralja 1993 g. "Osnovy zakonodatel'stva Rossijskoj Federacii o notariate” // Vedomosti S\#ezda narodnyh deputatov Rossijskoj Federacii i Verhovnogo Soveta Rossijskoj Federacii. [Law of the Russian Federation of February 11, 1993 "Fundamentals of legislation of the Russian Federation on notaries" / / Vedomosti of the Congress of people's deputies of the Russian Federation and the Supreme Soviet of the Russian Federation.] - 1993. - no. 10. - St. 357. 